\title{
Muskrats in Winter
}

\section{Fred W. Lahrman, Regina}

VERY often we learn something

new about our most common animals and birds, which makes us realize more and more how admirably they adapt themselves to seasonal changes, weather conditions, etc. As each new page in their lives is turned, we feel a deeper appreciation and sympathy for the story of their lives. Sometimes we find the page by mere chance, sometimes it is pointed out to us by a friend, and often we find that it had been open to us all the time, if only we had been observant enough to see it.

It was on a brisk sunny morning early in November that I learned something more about how the Muskrat is able to live and carry on its daily activities, even though its world has become a frozen solid mass of ice. While Mr. Bard and I were driving past Tregarva slough, we noticed several Muskrat houses and pushups jutting up through the ice and snow. Stopping to investigate, Mr. Bard pointed out a series of runways which were clearly visible under the ice, leading out in several different directions from the nearest house. Following one of these we soon found a muskrat travelling along the runway. It caught sight of us and let out a little stream of bubbles as it slowly sank from sight. As the ice was not yet frozen to the bottom, he was able to travel another route.

These runways lead and branch out from house to house and from one pushup to another where they pause for air. By continued use of these runways, the yare able to keep thein open all winter, even though the ice freezes to the bottom, and the Muskrat is able to keep in touch with all of his favorite Marsh and food supply.

\section{BRUNO}

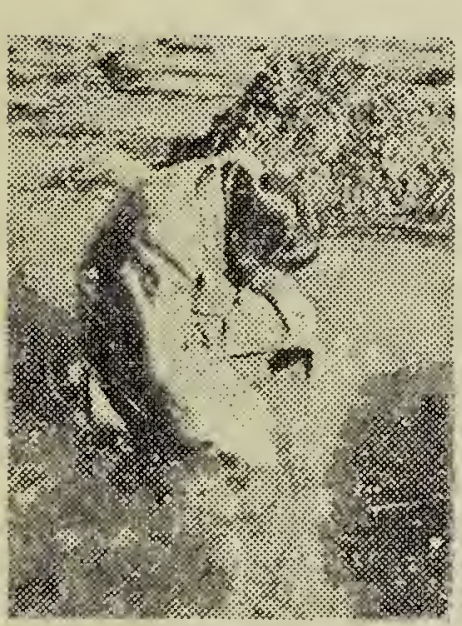

$\mathbf{A}^{\mathrm{s}}$

Evelyn Casson, Cater, Sask.

$\mathrm{S}$ winter draws

c los er the bears around our district are going about the business of putting on those layers of fat that are so important to them for $t$ h e i $r$ long winter period of hibernation.

As there was very little wild fruit around here this year the bears have been seen raiding the crops of ripened grain to fatten on the rich kernels of wheat and barley. Although I have lived in this district many years and each summer I have seen signs of bears, this fall was the first time I have had the good fortune to see a bear in the wild state.

One afternoon about the first of September "the boss" was stooking barley in a field west of the house. He was working near a clump of black poplars. He had just finished stooking one row and was starting on the next when something caused him to glance back and there at the stook he had just set up was a bear calmly pulling out barley stalks and eating off the heads. To say he was startled would be putting it mildly. If he had seen the bear in the distance first or had had any warning one was near by it wouldn't have startled him so much, but to turn around and to find one so close was just too much - so he came home.

Together we walked back to the field to see if it might still be there. Sure enough, there he was, sitting in the shade of a black poplar munching the heads of a barley sheaf. We walked to within fifty feet of him before he saw us. When he did so and stood up he seemed to be over five feet tall.

As we turned to go we saw him calmly sit down again and go on with his dinner which we had so rudely interrupted.

For a day or two afterward the boys were out with the rifle to see if they could get him. I hoped in my heart they wouldn't find him. They didn't - not a trace. I hope they never find him and I like to think he may live to enjoy many summers of sunshine and good barley sheaves and long winter sleeps in some snug den under a windfall. 